Available online at GSC Online Press Directory

GSC Biological and Pharmaceutical Sciences

e-ISSN: 2581-3250, CODEN (USA): GBPSC2

Journal homepage: https://www.gsconlinepress.com/journals/gscbps

(RESEARCH ARTICLE)

\title{
Herbaceous species diversity in Veerani Aloor, Kanyakumari district, Tamilnadu, South India
}

\author{
Kensa VM *, Chinnu M and Lekshmi JL \\ P.G. Department of Botany and Research Centre, S.T. Hindu College, Nagercoil -629 002, M.S University, Abishehapatti, \\ Tirunelveli, Tamil Nadu, India
}

Publication history: Received on 03 July 2018; revised on 03 September 2018; accepted on 10 September 2018

Article DOI: https://doi.org/10.30574/gscbps.2018.4.3.0060

\begin{abstract}
Herbaceous plant species are important components of ecosystems. Herbs are variable in their presence as well as presence of certain chemical compounds in their body system. Floristic studies acquire increasing importance in recent years in response to the need of developing and understand and under developing countries to assess their plant wealth. Total 54 plant species belonging to 20 families and 48 genera were recorded from the study site. Out of 54 plants, 54 were angiosperms. The contribution of dicotyledons was $98 \%$ and monocotyledons $2 \%$. Acanthaceae was the most dominant family with 6 species and 6 genera and other main contributing families were Amaranthaceae ( 7 species and 6 genera), Euphorbiaceae ( 6 species and 4 genera), Apocynaceae ( 5 species and 5 genera), Capparaceae ( 3 species and 3 genera) and Malvaceae ( 3 species and 3 genera). The most dominant life from was wild (87\%) followed by ornamental (12\%) and cultivation (2\%). The dominance of plants from Poaceae, Euphorbiaceae and Apocynaceae families in the study site, supports the harsh environmental conditions especially the water stress, because these plants have made morphological, anatomical and a physiological modifications to overcome the drought conditions. Dominance of Papilionaceae shows that these areas are nutrient deficient especially nitrogen.
\end{abstract}

Keywords: Angiosperms; Dominance; Cultivation; Herbaceous; Morphological

\section{Introduction}

Herbs are major components of plant diversity and are an important segment of global biodiversity. These are also remarkable for their presence in wide range and for a major source of medicine and aroma for human beings. Herbs are variable in their presence as well as presence of certain chemical compounds in their body system. Among a mega diversity of the plants some herbs are of significant medicinal as well as a source of aromatic values. The composition of herbaceous vegetation varied according to the climate and land use conditions. According to [1], herbs are usually small tender plants, lacking of woody stems above ground. Floristic studies acquire increasing importance in recent years in response to the need of developing and understand and under developing countries to assess their plant wealth [2]. The aim of the present research was to explore and assesses the Plant diversity especially herbaceous plants in Veerani village. This study is helpful to evaluate the plant species diversity in the selected area.

\section{Material and methods}

\subsection{Description of the study area}

Veerani village area is selected for a present study. It comes under Aloor town panchyat. It is situated just about $8 \mathrm{~km}$ from Nagercoil municipality. The total area of this village is approximately 80 acres. These areas occupy nearly 800-900

\footnotetext{
${ }^{*}$ Corresponding author

E-mail address: surejkensa@gmail.com
}

Copyright (C) 2018 Author(s) retain the copyright of this article. This article is published under the terms of the Creative Commons Attribution Liscense 4.0. 
people. These people mainly depend on construction works, agricultural works for job and income. In olden days these areas are had a thick vegetation and other cultivation. But now a days the vegetation are destroyed by human activities for building houses, schools, temples, ponds, marriage hall and parks. These people destroyed huge amount of trees used for firewood purposes. In recent days they are affected by different climatic factors (i.e.) low rainfall, high temperature and other seasonal variations etc. So naturally the vegetation is slowly destroyed. This study shows the latest survey of herbs in this area.

\subsection{Floristic survey}

Present survey was conducted in the plant species growing in their natural habitats like grounds, roadsides, open land gardens. Plant specimens were collected (depending upon their availability) from the area under investigation. These specimens were identified and photographed. Maximum plants have been photographed in their natural habitat whereas others in the laboratory conditions. All species have been designated to their corresponding families. Plant species were also differentiated on the basis of their habit. Herbarium sheets were prepared and documented. Identification was done with the help of different floras [3-5].

\section{Results and discussion}

Total 54 plant species belonging to 20 families and 48 genera were recorded from the study site (Table 1). Out of 54 plants, 54 were angiosperms. The contribution of dicotyledons was $98 \%$ and monocotyledons $2 \%$ (Table 2). Acanthaceae was the most dominant family with 6 species and 6 genera and other main contributing families were Amaranthaceae ( 7 species and 6 genera), Euphorbiaceae ( 6 species and 4 genera), Apocynaceae ( 5 species and 5 genera), Capparaceae ( 3 species and 3 genera), Malvaceae ( 3 species and 3 genera) (Table-4). The most dominant life from was wild (87\%) followed by ornamental (12\%) and cultivation (2\%) (Table 3).

Table 1 List of plant species recorded from the study area

\begin{tabular}{|c|c|c|c|c|}
\hline $\begin{array}{l}\text { Sr. } \\
\text { No. }\end{array}$ & Name of the plants & $\begin{array}{l}\text { Wild/ } \\
\text { Cultivate/Ornamental }\end{array}$ & Family & $\begin{array}{l}\text { Number of } \\
\text { cotyledons }\end{array}$ \\
\hline 1 & Abutilon indicum (L.) Sweet. & Wild & Malvaceae & Dicot \\
\hline 2 & Achyranthes aspera L. & Wild & Amaranthaceae & Dicot \\
\hline 3 & Aerva lanata (L.) Juss. Ex. Schult. & Wild & Amaranthaceae & Dicot \\
\hline 4 & Allamanda cathartica $\mathrm{L}$. & Ornamental & Apocynaceae & Dicot \\
\hline 5 & Alternanthera tenella colla & Wild & Amaranthaceae & Dicot \\
\hline 6 & Asystasia gangetica (L.) T. Anderson. & Wild & Acanthaceae & Dicot \\
\hline 7 & Barleria mysorensis Heyne. & Wild & Acanthaceae & Dicot \\
\hline 8 & Barleriaa luplina Lindl. & Wild & Acanthaceae & Dicot \\
\hline 9 & Boerhaavia diffusa $\mathrm{L}$ & Wild & Nyctaginaceae & Dicot \\
\hline 10 & Calotropis gigantea R. Br. & Wild & Apocynaceae & Dicot \\
\hline 11 & Cassia occidentalis (L.) Link & Ornamental & Fabaceae & Dicot \\
\hline 12 & Catharanthus roseus (L.) G. Don. & Ornamental & Apocynaceae & Dicot \\
\hline 13 & Celosia argentea $\mathrm{L}$. & Wild & Amaranthaceae & Dicot \\
\hline 14 & Cleome retidosperma DC. & Wild & Capparaceae & Dicot \\
\hline 15 & Cleome viscosa $\mathrm{L}$. & Wild & Capparaceae & Dicot \\
\hline 16 & Commelina benghalensis Linn. & Wild & Commelinaceae & Monocot \\
\hline 17 & Crossandra infundibuliformis (L.) Nees. & Ornamental & Acanthaceae & Dicot \\
\hline 18 & Crotalaria juncea $\mathrm{L}$. & Wild & Fabaceae & Dicot \\
\hline 19 & Croton hirtus L. Her. & Wild & Euphorbiaceae & Dicot \\
\hline 20. & Croton sparsiflorus morong & Wild & Euphorbiaceae & Dicot \\
\hline 21. & Cyanotis axillaris (L.) D. Don ex Sweet. & Wild & Commelinaceae & Monocot \\
\hline 22. & Duranta plumeri Jacq & Wild & Verbinaceae & Dicot \\
\hline
\end{tabular}




\begin{tabular}{|c|c|c|c|c|}
\hline 23. & Euphobia heterophylla L. & Wild & Euphorbiaceae & Dicot \\
\hline 24. & Euphobia hista L. & Wild & Euphorbiaceae & Dicot \\
\hline 25. & Evolvulus alsinoides (L.) & Wild & Convolvulaceae & Dicot \\
\hline 26. & Gamphrena celosioides Mart. & Wild & Amaranthaceae & Dicot \\
\hline 27. & Gardenia gummifera L.F & Ornamental & Rubiaceae & Dicot \\
\hline 28. & Gomphrena globosa $\mathrm{L}$. & Ornamental & Amaranthaceae & Dicot \\
\hline 29. & Gynandropsis pentaphylla (L.) DC. & Wild & Capparaceae & Dicot \\
\hline 30. & Heliotropium indicum L. & Wild & Boraginaceae & Dicot \\
\hline 31. & Hybanthus enneaspermus (L.) F. Muell. & Wild & Violaceae & Dicot \\
\hline 32. & Hyptis suaveolens (L.) poit & Wild & Lamiaceae & Dicot \\
\hline 33. & Indigofera tinctoria $\mathrm{L}$. & Wild & Fabaceae & Dicot \\
\hline 34. & Ipomea carnea Juce. & Wild & Convolvulaceae & Dicot \\
\hline 35. & Jasminum multiflorum (Burm.f.) & Wild & Oleaceae & Dicot \\
\hline 36. & Jatropha gossypifolia Carl Linnaeus. & Wild & Euphorbiaceae & Dicot \\
\hline 37. & Jusficia tranguebariensis $\mathrm{L}$. & Wild & Acanthaceae & Dicot \\
\hline 38. & Justicia gendarussa Burm.fil. & Wild & Acanthaceae & Dicot \\
\hline 39. & Kosteletzkya vitifolia (L.) M. R. Almeida & Wild & Malvaceae & Dicot \\
\hline 40. & Lantana camara L. & Wild & Verbenaceae & Dicot \\
\hline 41. & Malvastrum Coromandelianum (L.) garcke & Wild & Malvaceae & Dicot \\
\hline 42. & Mimosa pudica $\mathrm{L}$. & Wild & Mimosaceae & Dicot \\
\hline 43. & Parthenium hysterophorus L. & Wild & Asteraceae & Dicot \\
\hline 44. & Pavonia hastate Cav. & Wild & Malvaceae & Dicot \\
\hline 45. & Peristrophe bicalyculata (Retz.) Nees. & Wild & Acanthaceae & Dicot \\
\hline 46. & Plumbago zeylanica L. & Wild & Verbenaceae & Dicot \\
\hline 47. & Rauvolfia tetraphylla L. & Wild & Apocynaceae & Dicot \\
\hline 48. & Ricinus communis $\mathrm{L}$. & Wild & Euphorbiaceae & Dicot \\
\hline 49. & Ruellia tuberosa L. & Wild & Acanthaceae & Dicot \\
\hline 50. & Sesamum indicum L. & Cultivation & Pedaliaceae & Dicot \\
\hline 51. & Solanum torvum Sw. & Cultivation & Solanacea & Dicot \\
\hline 52. & Synedrella nodiflora (L.) Gaertn. & Wild & Asteraceae & Dicot \\
\hline 53. & Thevitia peruviana (Bers.) K. Schum & Wild & Apocynaceae & Dicot \\
\hline 54. & Vernonia cinerea (L.)Less. & Wild & Asteraceae & Dicot \\
\hline
\end{tabular}

Table 2 Cotyledon wise distribution

\begin{tabular}{clcc}
\hline Sr. No. & Presence of cotyledons & Number of plants & Percentage (\%) \\
\hline 1 & Dicots & 52 & 96 \\
2 & Monocots & 2 & 4 \\
\hline
\end{tabular}

Table 3 Percentage of plant species under wild/cultivated, ornamental categories

\begin{tabular}{clcc}
\hline Sr. No. & Nature of plants & Number of species & Percentage (\%) \\
\hline 1 & Wild & 47 & 87 \\
2 & Ornamental & 6 & 12 \\
3 & Cultivated & & 2 \\
\hline
\end{tabular}


Table 4 Dominant and least family

\begin{tabular}{clc}
\hline Sr. No. & \multicolumn{1}{c}{ Family } & Number of plants \\
\hline 1 & Acanthaceae & 8 \\
2 & Amaranthaceae & 7 \\
3 & Euphorbiaceae & 6 \\
4 & Apocynaceae & 5 \\
5 & Capparaceae & 3 \\
6 & Fabaceae & 3 \\
7 & Malvaceae & 3 \\
8 & Verbenaceae & 3 \\
9 & Asteraceae & 3 \\
10 & Polygonaceae & 1 \\
11 & Nyctaginaceae & 1 \\
12 & Rubiaceae & 1 \\
13 & Boraginaceae & 1 \\
14 & Violaceae & 1 \\
15 & Lamiaceae & 1 \\
16 & Oleaceae & 1 \\
17 & Mimosaceae & 1 \\
18 & Pedaliaceae & 1 \\
19 & Convolvulaceae & 2 \\
20 & Commelinaceae & 2 \\
\hline & & \\
\hline
\end{tabular}

A number of workers have drawn attention towards the threatened plants of India from time to [8]. In the recent years an increasing attention has been paid on the conservation of rare and threatened species especially on medicinal plants through ex-situ and in-situ practices. The indigenous knowledge is an important tool for study of natural resources that has enormous potential to facilitate development process in cost-effective and sustainable ways. In governs almost all important productive resource sectors and revolves around traditional values of resource use. The local inhabitants and the forest dwellers have their own knowledge about the utilization and conservation of plant which passes from generation to generation so it is important to record such knowledge from these people for proper assessment and conservation to the benefit of mankind.

Conservation of natural resources is a matter of vital interest to man from ancient time India is playing an important role in the conservation of biological diversity and sustainable development through its own biological diversity act and rules. The biodiversity has become such an important challenge to the whole world that it has invented attention from various disciplines, people as well as all quarters of the world. There is a strong need to conserve over exploited species due to large scale of their uses and collection from natural habitats. It is showed that documenting indigenous knowledge through ethno botanical studies is important for the conservation of biological and cultural diversities. This makes a great threat to the survival of many wild species and the ecosystems which are of great economic value to the mankind.

The herb community of tropical forests is very little known, with few studies addressing its structure quantitatively. Even with this scarce body of information, it is clear that the herbs are a rich group, comprising 14 to $40 \%$ of the species found in total species counts in tropical forests. This stratum remains an underappreciated aspect of forest ecosystems. The documentation and classification of this unique and often neglected vegetation community may enable efforts to be made for biological conservation [9]. The problem is that due to over collection and climate change several species are 
fast disappearing. The dominance of families of Poaceae, Fabaceae, Cyperaceae, and Malvaceae in all study areas reflects that these families are the most frequent in Savanna herbaceous vegetation in West Africa. The Poaceae family is well represented, as grasses are the largest family of vascular plants in Savannas. The difference in herbaceous vegetation composition is related to the dual effect of climate and land use conditions. Climate conditions explain the difference in species composition between different climate zones.

Land use causes differences in species composition within a climate zone. Indeed, human disturbances influence composition and distribution of plant species. Patterns of species richness and cover are determined by multiple environmental factors (climate change and human activities) .Generally, local species richness and diversity of Savanna ecosystems are maintained by dynamic interactions between local colonization from species pools at larger spatial scales and local extinction due to competitive exclusion. The frequency of herbaceous species is more influenced by the interaction between climatic conditions and land use regimes than their separate effects. In fact, the distribution of herbaceous species is principally affected by climate, which determines geographical affinity and land use, which affects the spatial heterogeneity of vegetation and influences ecosystem processes. This results in the fact that a species which is the most frequent under a given climate and land use condition becomes rare under other climate and land use conditions.

\section{Conclusion}

At present time, several of the important plant species are on verge of depletion, therefore such type of studies shall be paid serious attention for future prospects and to understand the use pattern in terms of sustainability and conservation Sustainability of forest ecosystem is an essential component of the environmental conservation efforts and any degradation of forest. It is also observed that successful strategies for management of useful species would be beneficial for future prospects.

\section{Compliance with ethical standards}

\section{Acknowledgments}

The authors are thankful to Department of Botany, S. T. Hindu College for providing necessary facilities for carrying out the work.

\section{Disclosure of conflict of interest}

We declare that we have no conflict of interest.

\section{References}

[1] Hornby AS. (2001). Oxford Advanced Learners Dictionary. 6th Edition. Oxford University Press, Oxford, New York, 580 .

[2] Vediya SD and Kharad HS. (2011). Floristic diversity of Isarizone, Megharj range forest district Sabarkantha Gujarat, India. International Journal of Pharmacy and Life science, 2(9), 1033-1034.

[3] Gamble JS and Fischer CE. (1915-1935). Flora of the Presidency of Madras. Vols. I-III, Adlard\& Co., London.

[4] Mathew KM. (1983). The flora of Tamil Nadu Carnatic. Volume 3, Diosceesam Press, Madras.

[5] Nair NC and Henry AN. (1983). Flora of Tamil Nadu, India, Series I. Analysis Vol. 1, Botanical Survey of India, Coimbatore.

[6] Vashistha BD and Mandeep Kaur R. (2013). Floristic and ethno botanical survey of Ambala District, Haryana. International Journal of Pharma and Bio Sciences, 4(2), 353-360.

[7] IUCN. (1980). World conservation strategy Living resource conservation for sustainable development, IUCN: UNEP/WWF, Gland, Switzerland.

[8] Jain SK and Shastry ARK. (1980). Threatened plants of India-A state of the Art Report.

[9] Ahmad SS and Ehsan H. (2012). Analyzing the herbaceous flora of LohiBher Wildlife Park under variable environmental stress. Pakistan Journal of Botany, 44(1), 11-14. 
Kensa et al. / GSC Biological and Pharmaceutical Sciences 2018, 04(03), 068-073

\section{How to cite this article}

Kensa VM, Chinnu M and Lekshmi JL. (2018). Herbaceous species diversity in VeeraniAloor, Kanyakumaridistrict, Tamilnadu, South India. GSC Biological and Pharmaceutical Sciences, 4(3), 68-73. 